Urol. int. 1978;33:1-2

\title{
Contents, Vol. 33, No. 1-3, 1978
}

Ulmsten, U.; Sjöberg, N.-O.; Andersson, K.-E.; Owman, C, and Walles, B. (Lund): A

New Contribution to the Discussion of the Existence of a Urethral Sphincter

Mechanism in the Female 3

Boyarsky, S. and Labay, P. (Saint Louis, Mo.): Principles of Bladder Function 4

Mastrigt, R. van; Coolsaet, B.L.R.A., and Duyl, W.A. van (Rotterdam): The Passive

Properties of the Urinary Bladder in the Collection Phase 14

Torrens, M.J. (Bristol): Urethral Sphincteric Responses to Stimulation of the Sacral

Nerves in the Human Female 22

Jonas, U. and Hohenfellner, R. (Mainz): A New Concept of Urodynamic Evaluation of

the Lower Urinary Tract 27

Duyl, W.A. van; Coolsaet, B.L.R.A., and Mastrigt, R. van (Rotterdam): A New Clinical

Parameter for the Assessment of the Contractility of the Urinary Bladder 31

Andersen, J.T. and Bradley, W.E. (Minneapolis, Minn.): Urethral Pressure Profilometry.

Assessment of Urethral Function by Combined Intravesical Pressure and EMG

Recording $\quad 40$

Duyl, W.A. van; Zwart, A. van der; Rikken, H., and Roggeveen, H. (Rotterdam): An

Electronic Device for Quick Analysis of Exponential Decay Curves

50

Palmtag, H. and Heering, H. (Heidelberg): Signs of Compensation and Decompensation in Bladder Outlet Obstruction 53

Nordling, /.; Hebjørn, S.; Walter, S.; Hald, T., and Christiansen, H.D. (Copenhagen): A Comparative Study of Water Cystometry and C02 Cystometry in 102 Consecutive

Patients 60

Mortensen, S.; Diurhuus, J.C; Frimodt-M $\varphi$ ller, C, and Petersen, E. (Copenhagen): The Diagnostic Value of Urethral Pressure Profiles, Cystometry, Pressure-Flow Studies and Micturition Cystourethrography in Female Incontinence 68 Whit field, H.N.; Perry, I.R., and Hill, D.W.: Computer Analysis of Detrusor Electromyograms 74

Erlandson, B.E. and Fall, M. (Göteborg): Urethral Pressure Profile Studied by Two Different Microtip Transducers and an Open Catheter System 79

Heidler, H.; Kiesswetter, H., and Flamm, J. (Vienna): The Influence of Acid and Alkaline Media on Urodynamic Parameters 83

Rollema, H.J. (Rotterdam): Ultrasonic Volumetry, a New Principle for Uroflowmetry; Comparison with the DISA Mictiometer $\quad 88$

Index 2

Turner Warwick, R. (London): The Treatment of Female Urinary Incontinence .... 101 Öbrink, A.; Bunne, G., andIngelman-Sundberg, A. (Stockholm): The Urethral Pressure Profile in Urge Incontinence before and after Unilateral Blockade of the Inferior Hypogastric Plexus 107 
Henriksson, L.; Asmussen, M.; Löfgren, O., and Ulmsten, U. (Malmö): A Urodynamic Comparison between Abdominal Urethrocystopexy and Vaginal Sling Plasty in Female Stress Incontinence Ill

Faber, P.; Beck, L·, and Heidenreich, J. (Düsseldorf): Treatment of Urinary Stress Incontinence in Women with the Lyodura Sling 117

Hebjprn, S. and Walter, S. (Gentofte): Treatment of Female Incontinence with Emepronium Bromide. Detrusor Hyperreflexia in Multiple Sclerosis and Urge Incontinence in Postmenopausal Women, Treated with Emepronium Bromide $($ Cetiprin $\mathbb{R}) \quad 120$

Michiels, H.G.E.; Delaere, K.P.J.; Debruyne, F.M.J., and Moonen, W.A. (Nijmegen): Treatment of Nonneurogenic Unstable Bladder by Prolonged Bladder Distension.

A Review of 22 Cases 130

Walter, S.; Wolf, H; Barlebo, H., and Kaalund Jensen, H. (Gentofte): Urinary Incon tinence in Postmenopausal Women Treated with Estrogens. A Double-Blind Clinical Trial 135

Walter, S.; Olesen, K.P.; Kaalund Jensen, H., and Hjortkær Pedersen, P. (Gentofte): Urinary Stress Incontinence in Women. Pre- and Postoperative Evaluation .... 144 Bologna, U. (Rome): A New Surgical Procedure for the Correction of Urinary Stress Incontinence in the Female 150

Blandy,J. (London): The Indications for Prostatectomy 159

Abrams, P.H. and Feneley, R.C.L. (Bristol): The Significance of the Symptoms Associated with Bladder Outflow Obstruction 171

Madersbacher, H; Marberger, H., and Holl, P. (Innsbruck): Hydrodynamic Aspects of Bladder Neck Obstruction 175

Abrams, P.H. (Bristol): The Urodynamic Changes following Prostatectomy

Hohenfellner, R. and Jonas, U. (Mainz): Results following Prostatectomy 187

Andersen, J.T. and Nordling, J. (Gentofte): Urinary Incontinence after Transvesical

Prostatectomy 191

Jonas, U. and Hohenfellner, R. (Mainz): Which Anatomical Structures in Fact Achieve Urinary Continence? 199 